\title{
PENILAIAN RELATIF EKOSISTEM GUMUK PASIR SEBAGAI KAWASAN KONSERVASI ATAU PERTAMBANGAN DI PANTAI SELATAN DAERAH ISTIMEWA YOGYAKARTA
}

\author{
Farida Afriani Astuti ${ }^{1}$, Andi Sungkowo ${ }^{1}$, Eni Muryani ${ }^{1}$ \\ ${ }^{1}$ Program Studi Teknik Lingkungan, Fakultas Teknologi Mineral, UPN "Veteran” Yogyakarta \\ Jl. SWK 104, Condongcatur 55283, Yogyakarta, Indonesia \\ faridaafriani.astuti@gmail.com; andi.sungkowo@yahoo.com; enimuryani@gmail.com
}

\begin{abstract}
Intisari - Ekosistem gumuk pasir memiliki manfaat secara ekonomi dan non ekonomi sehingga berpotensi menimbulkan konflik kepentingan dalam upaya pemanfaatannya. Penelitian ini bertujuan untuk menilai secara relatif pemanfaatan dan pengelolaan ekosistem gumuk pasir sebagai kawasan konservasi atau sebagai kawasan pertambangan dengan pendekatan ekonomi lingkungan. Metode yang digunakan pada penelitian ini adalah dengan cara penilaian relatif. Penilaian ini bersifat prediksi dengan pendekatan pengharkatan. Nilai harkat dilakukan pada setiap makna dari manfaat ekosistem gumuk pasir dan ditentukan berdasarkan pertimbangan kepakaran (professionalism judgment). Keterkaitan antara ekosistem gumuk pasir sebagai kawasan konservasi dengan kawasan pertambangan menghasilkan dua macam hubungan, yaitu hubungan negatif antara pertumbuhan kebutuhan pasir besi dengan tersedianya pasir besi di dalam gumuk pasir dan hubungan positif antara pertumbuhan eksploitasi pasir besi dengan kerusakan gumuk pasir. Berdasarkan jumlah harkat terhadap penilaian manfaat ekosistem gumuk pasir sebagai kawasan konservasi atau kawasan pertambangan dihasilkan bahwa pilihan/opsi konservasi lebih besar nilainya dengan selisih 9 (52,63\%) terhadap opsi pertambangan. Dengan demikian ekosistem gumuk pasir di Pantai Selatan DIY sebaiknya dijadikan sebagai kawasan konservasi.
\end{abstract}

Kata kunci: gumuk pasir, konservasi, pertambangan

\section{PENDAHULUAN}

\subsection{Latar Belakang}

Ekosistem gumuk pasir merupakan bagian dari potensi sumberdaya pesisir dan laut yang memiliki peran yang sangat penting bagi kehidupan manusia. Tidak semua negara memiliki potensi sumberdaya pesisir berupa ekosistem gumuk pasir. Indonesia menjadi negara yang beruntung karena memiliki ekosistem gumuk pasir yang sangat luas. Gumuk pasir yang ada di Indonesia salah satunya terdapat di Pantai Selatan Provinsi DIY (Parangtritis - Kabupaten Bantul) sampai Jawa Tengah (Ambal - Kabupaten 'Kebumen). Secara umum bentuk gumuk pasir yang ada di sana adalah tipe barchan, parabolik, sisir, transversal dan memanjang membentuk tanggul pasir (tanggul alam) yang relatif sejajar dengan garis pantai. Barchan terbentuk karena lokasi yang relatif datar dan tanpa penghalang. Sedangkan gumuk pasir parabolik terbentuk akibat adanya vegetasi penghalang.

Gumuk pasir merupakan proses bentukan lahan asal angin (aeolin process) dan memiliki sifat aktif/dinamis. Bertambah dan berkembangnya bentuk lahan gumuk pasir, selaras dengan suplai material hasil aktivitas gunungapi yang ditranspor melalui sungai dan diendapkan pada muara sungai, oleh arus dan ombak air laut kemudian diendapkan di pantai sebagai endapan marin (marine process). Disamping gumuk pasir memiliki proses pembentukan yang cukup kompleks 
(multigenetik), gumuk pasir ternyata mengandung biji besi. Menurut Indarti (2008), unsur besi (Fe) dan $\mathrm{TiO}_{2}$ yang didapatkan di Pantai Bogowonto berkadar: Fe total (11,39\% - 16,91\%), $\mathrm{FeO}(5,40 \%$ - 7,46\%), $\mathrm{Fe}_{2} \mathrm{O}_{3}\left(10,28 \%\right.$ - 15, 89\%) dan $\mathrm{TiO}_{2}(1,65 \%$ - 2,13\%).

Keberadaan biji besi tersebut memicu masyarakat untuk membuat rencana kegiatan penambangan sehingga dikhawatirkan dapat mengganggu kelestarian gumuk pasir. Selain memiliki manfaat secara ekonomi (kegiatan penambangan) ekosistem gumuk pasir juga memiliki manfaat non ekonomi (konservasi). Adapun manfaat non ekonomi dari ekosistem gumuk pasir antara lain sebagai tempat pendidikan, penelitian, rekreasi, olahraga, pendukung tata air, barrier bencana tsunami, melestraikan kanekaragaman hayati, dan sebagainya. Mengingat pentingnya manfaat dari ekosistem gumuk pasir ini maka terdapat dua pilihan/opsi dalam memanfaatkan dan mengelola ekosistem gumuk pasir yaitu sebagai kawasan konservasi atau sebagai kawasan pertambangan.

\subsection{Tujuan}

Tujuan dari penelitian ini adalah menilai secara relatif antara pemanfaatan dan pengelolaan ekosistem gumuk pasir sebagai kawasan konservasi atau sebagai kawasan pertambangan dengan pendekatan ekonomi lingkungan.

Adapun manfaat dari penelitian ini adalah sebagai bahan pertimbangan dan masukan bagi para pengambil keputusan terhadap opportunity cost dari upaya pemanfaatan ekosistem gumuk pasir, baik berdasarkan nilai ekonomi langsung maupun tidak langsung. Dengan diketahuinya nilai ini diharapkan dapat dikembangkan secara lebih tepat kebijakan pemanfaatan dan pengelolaan ekosistem gumuk pasir sesuai dengan prinsip pembangunan berkelanjutan.

\section{METODOLOGI}

Metode yang digunakan pada penelitian ini adalah dengan cara penilaian relatif. Penilaian ini bersifat prediksi dengan pendekatan relatifitas pengharkatan (skoring). Nilai harkat dilakukan pada setiap makna dari manfaat ekosistem gumuk pasir dan ditentukan berdasarkan pertimbangan kepakaran/pribadi (professionalism judgment). Hasil dari penilaian tersebut kemudian dibandingkan dan digunakan untuk menentukan pilihan pemanfaatan dan pengelolaan ekosistem gumuk pasir sebagai kawasan konservasi atau pertambangan.

\section{HASIL DAN PEMBAHASAN}

\subsection{Keterkaitan Ekosistem Gumuk Pasir sebagai Kawasan Konservasi dan Pertambangan}

Ekosistem gumuk pasir sebagai kawasan konservasi memiliki manfaat yang sangat besar bagi kehidupan manusia di masa kini hingga masa depan. Manfaat tersebut antara lain sebagai pencegah/penghambat intrusi air asin, pengatur iklim mikro, pembentuk lapisan tanah, barrier 
bencana tsunami, wisata bahari, dan sebagainya. Manfaat yang besar ini juga diiringi oleh kerentanan terhadap perubahan lingkungan. Hal ini disebabkan karena ekosistem gumuk pasir memiliki daya dukung yang rendah dan sukar diperbaiki jika sudah terlanjur rusak. Secara alami gumuk pasir bisa mengalami deflasi pasir. Deflasi adalah perpindahan 'material pasir atau debu oleh aktifitas angin (Mardiyatno dan Sunarto, 2000). Deflasi pasir memiliki pengaruh terhadap kenyamanan lingkungan disekitarnya seperti menggaggu penglihatan dan pernafasan serta penimbunan pasir di area persawahan dan permukiman. Adanya deflasi pasir mengakibatkan terjadinya penambahan endapan pasir atau bisa diartikan sebagai input dalam proses pembentukan gumuk pasir.

Menurut Aprilia (2003) deflasi pasir pada tiap tipe gumuk pasir berbeda-beda. Deflasi pasir pada gumuk pasir tipe barchan sebesar 233,5 gram/jam, pada tipe barchanoid sebesar 440,97 gram/jam, pada tipe transversal aktif sebesar 115,07 gram/jam, pada tipe transversal inaktif sebesar 41,36 gram/jam, dan pada tipe nebkha sebesar 170,06 gram/jam. Data tersebut menunjukkan bahwa penambahan endapan pasir sebagai input dalam proses pembentukan gumuk pasir berjalan sangat lambat. Kondisi inilah yang menjadi alasan untuk selalu menjaga kelestarian gumuk pasir, karena proses pembentukkannya yang sangat lama namun bisa dirusak dalam waktu yang sangat singkat baik oleh aktivitas manusia maupun secara alami.

Aktivitas manusia yang berpotensi merubah ekosisitem gumuk pasir salah satunya adalah kegiatan ekonomi yang dilakukan oleh masyarakat. Kegiatan penambangan pasir besi dan material urug sebagai kegiatan ekonomi masyarakat dikhawatirkan dapat mengganggu kelestarian gumuk pasir. Penambangan pasir besi dan material urug yang direncanakan oleh masyarakat akan mempengaruhi pengurangan bentuk, volume, penyebaran, dan ketinggian gumuk pasir. Pengurangan bentuk dan volume akibat rencana kegiatan tersebut tidak sebanding dengan proses penambahan endapan pasir akibat adanya deflasi pasir.

Perbandingan antara proses penambahan endapan pasir dan aktivitas penambangan pasir yang tidak seimbang dapat dilihat pada rencana penambangan pasir besi yang akan di laksanakan di Kabupaten Kulon Progo. Secara umum penambangan pasir besi dilakukan untuk memenuhi kebutuhan bahan baku pembuatan konsentrat yang akan diproses menjadi pig iron. Untuk mendapatkan bahan baku tersebut maka dibutuhkan penggalian pasir pantai sebesar $20 \%$ dari total luas penambangan (lahan pantai) dengan kedalaman penggalian antara 6-9 m. Perbedaan kedalaman penggalian tersebut dipengaruhi oleh kandungan pasir besi dan ketebalan depositnya. Jika luas penambangan pasir besi $1,2 \mathrm{~km}^{2}$ dengan kedalaman penggalian $6 \mathrm{~m}$ maka volume pasir pantai yang digali untuk menghasilkan konsentrat adalah sebesar $1.440 .000 \mathrm{~m}^{3}$. Sedangkan untuk kedalaman penggalian $9 \mathrm{~m}$ maka volume pasir pantai yang digali untuk menghasilkan konsentrat 
adalah sebesar $2.160 .000 \mathrm{~m}^{3}$. Dengan berat jenis pasir $1400 \mathrm{~kg} / \mathrm{m}^{3}$ maka untuk kegiatan penambangan, pasir yang terambil adalah sebesar 2.016.000 ton sampai dengan 3.024.000 ton.

Penambangan pasir tersebut banyak terjadi pada tipe gumuk pasir transversal baik aktif maupun inaktif. Berdasarkan data yang sudah dijelaskan sebelumnya deflasi pasir pada tipe transversal memiliki nilai rata-rata sebesar 78,22 gr/jam. Data tersebut menunjukkan bahwa penambahan endapan pasir berjalan sangat lambat. Dalam jangka waktu 1 bulan endapan pasir hanya bertambah sebesar 0,056 ton dan dalam jangka waktu 1 tahun bertambah 0,677 ton. Sedangkan pengambilan pasir pada kegiatan penambangan dalam satuan waktu tertentu adalah sebesar 2.016.000 ton sampai dengan 3.024.000 ton. Jika proses penggalian dilakukan selama 1 bulan maka kedua nilai tersebut dapat dibandingkan dan menghasilkan angka sebesar 1: 36.000 .000 sampai $1: 54.000 .000$. Hal ini menunjukkan pasokan pasir pembentuk gumuk pasir jauh lebih kecil dibandingkan dengan kehilangan pasir akibat kegiatan penambangan.

Keterkaitan antara ekosistem gumuk pasir sebagai kawasan konservasi dengan kawasan pertambangan dari kondisi diatas menghasilkan dua macam hubungan, yaitu:

a. Hubungan negatif antara pertumbuhan kebutuhan pasir besi dengan tersedianya pasir besi di dalam gumuk pasir. Artinya kenaikan kebutuhan pasir besi akan diikuti oleh menurunnya keberadaan gumuk pasir (Gambar 1). Kondisi ini dikarenakan proses eksploitasi pasir besi akan berdampak pada berkurangnya jumlah cadangan.

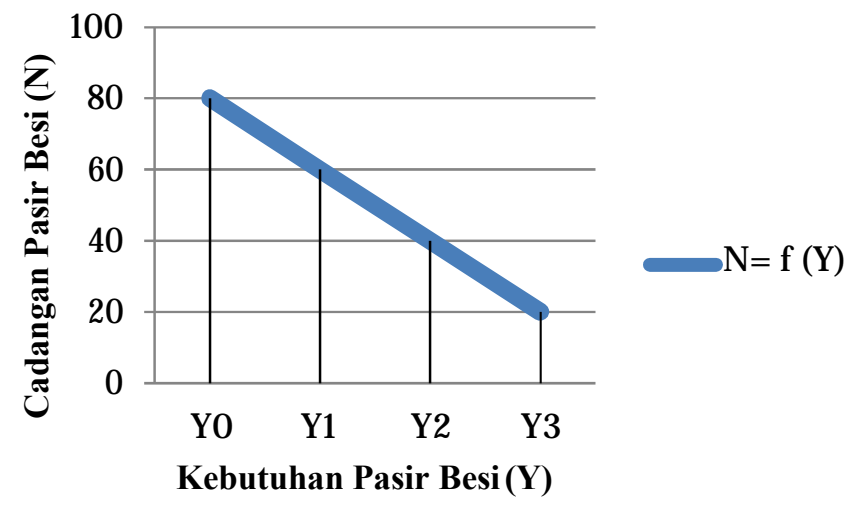

Gambar 1. Hubungan antara cadangan pasir besi dengan pertumbuhan kebutuhan pasir besi

b. Hubungan Positif antara pertumbuhan eksploitasi pasir besi dengan kerusakan gumuk pasir (Gambar 2). Kondisi ini dikarenakan eksploitasi pasir besi tidak disertai dengan upaya pencegahan terhadap kerusakan gumuk pasir yang ditimbulkan. Oleh karena itu, semakin tinggi eksploitasi pasir besi maka semakin tinggi pula tingkat kerusakan gumuk pasir. 


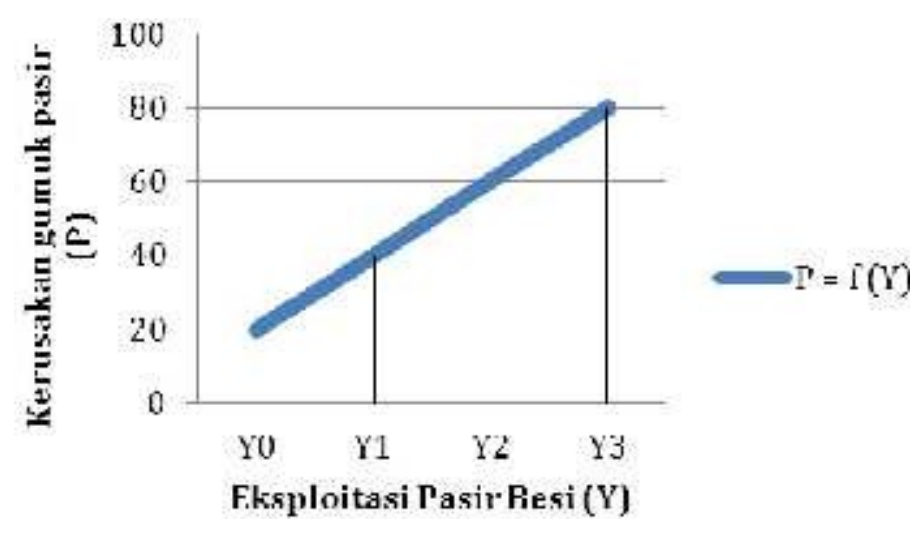

Gambar 2. Hubungan antara kerusakan gumuk pasir dengan eksploitasi pasir besi

Adanya pertumbuhan eksploitasi pasir besi akan menimbulkan dampak positif bagi kehidupan manusia dari sisi ekonomi yaitu tersedianya bahan baku (input) dalam proses produksi pig iron . Disisi lain menimbulkan dampak negatif bagi lingkungan yang nantinya juga akan berdampak pada kehidupan manusia itu sendiri. Misalnya eksploitasi pasir besi secara berlebihan akan mempercepat menipisnya cadangan pasir besi dan menimbulkan kerusakan gumuk pasir. Kerusakan gumuk pasir tersebut akan mengakibatkan berkurangnya daya tarik wisata, hilangnya tempat pendidikan dan penelitian ilmiah, terganggunya kegiatan sosial-budaya, serta dapat meningkatkan perluasan daerah risiko bencana tsunami.

Implikasi dari hubungan dan peran tersebut adalah bahwa lingkungan merupakan komponen penting dari sistem ekonomi. Artinya bahwa tanpa adanya lingkungan maka sistem ekonomi tidak akan berfungsi. Ini menyiratkan bahwa dalam sistem ekonomi, nilai lingkungan harus diperlakukan sama seperti halnya perlakuan terhadap nilai aset ekonomi (input produksi dan modal). Dengan demikian, pembangunan ekonomi yang seharusnya diterapkan adalah pembanguanan yang berwawasan lingkungan yaitu tidak menguras sumberdaya alam dan merusak lingkungan.

\subsection{Penilaian Relatif Ekosistem Gumuk Pasir}

Penilaian ekosistem gumuk pasir sebagai kawasan konservasi atau kawasan pertambangan dinilai berdasarkan hubungan aspek manfaat dengan ekonomi, yaitu:

a. Bermanfaat dan menguntungkan dengan risiko bencana kecil, dan

b. Bermanfaat tetapi merugi atau berisiko bencana besar.

Pengertian bencana dalam penilaian ini adalah berkaitan dengan korban harta benda dan/atau jiwa manusia. Adapun harkat yang digunakan dalam penilaian relatif terhadap ekosistem gumuk pasir didasarkan pada tabel 1. 
Tabel 1. Nilai Harkat Risiko Bencana

\begin{tabular}{|c|l|l|}
\hline Harkat & \multicolumn{1}{|c|}{ Kriteria } & \multicolumn{1}{c|}{ Sifat } \\
\hline 1 & Sangat besar risiko bencana & Sangat jelek \\
\hline 2 & Besar risiko bencana & Jelek \\
\hline 3 & Sedikit risiko bencana & Baik \\
\hline 4 & Sangat sedikit risiko bencana & Sangat baik \\
\hline
\end{tabular}

Hasil penilaian relatif keberadaan ekosistem gumuk pasir sebagai kawasan konservasi atau kawasan pertambangan ditunjukkan dalam tabel 2.

Tabel 2. Penilaian Relatif terhadap Ekosistem Gumuk Pasir

\begin{tabular}{|c|c|c|c|}
\hline \multirow{2}{*}{ No. } & \multirow{2}{*}{ Manfaat } & \multicolumn{2}{|c|}{ Pilihan/Opsi } \\
\hline & & Konservasi & Pertambangan \\
\hline 1 & Mencegah/menghambat intrusi air laut & 3 & 1 \\
\hline 2 & Pengatur iklim mikro & 3 & 2 \\
\hline 3 & Pembentuk lapisan tanah & 3 & 2 \\
\hline 4 & Barrier bencana tsunami & 4 & 1 \\
\hline 5 & Wisata bahari & 3 & 1 \\
\hline 6 & Lapangan kerja penduduk setempat & 3 & 3 \\
\hline & Jumlah harkat & 19 & 10 \\
\hline
\end{tabular}

Berdasarkan jumlah harkat terhadap penilaian manfaat ekosistem gumuk pasir sebagai kawasan konservasi atau kawasan pertambangan, dihasilkan bahwa pilihan/opsi konservasi lebih besar nilainya dengan selisih $9(52,63 \%)$ terhadap opsi pertambangan. Dengan demikian ekosistem gumuk pasir di Pantai Selatan DIY sebaiknya dijadikan sebagai kawasan konservasi.

\section{KESIMPULAN}

Besarnya manfaat yang diberikan oleh ekosistem gumuk pasir bagi kehidupan manusia, menjadikan gumuk pasir sebagai objek yang penting untuk diperhatikan. Manfaat ekonomi dan non ekonomi yang bisa diperoleh dari gumuk pasir menjadi permasalahan tersendiri terhadap pilihan pemanfaatan dan pengelolaan yang tepat. Selain itu proses pembentukan gumuk pasir yang memerlukan waktu lama yaitu ditunjukkan dengan penambahan endapan pasir sebesar 0,676 ton/th, diharapkan dapat membuat masyarakat berfikir ulang untuk melakukan kegiatan ekonomi yang berpotensi merusak ekosistem gumuk pasir. Berdasarkan konsep ekonomi lingkungan dan analisis sederhana dengan pemberian nilai relatif terhadap manfaat ekosisitem gumuk pasir, disimpulkan bahwa pilihan yang tepat terhadap pemanfaatan dan pengelolaan ekosistem gumuk pasir di Pantai Selatan DIY adalah sebagai kawasan konservasi dengan nilai pilihan/opsi sebesar 19. 


\section{Daftar Pustaka}

Aprilia, Aryani, 2003, Deflasi Pasir pada Berbagai Gumuk Pasir di Parangtritis, Skripsi, Fakultas Geografi UGM, Yogyakarta.

Flint, R.F. dan Skinner, B.J.,1977, Physical Geology, John Wiley \& Sons, Inc.

Indarto, 2008, Genesa dan Penyebaran Pasir Besi di Pantai Bogowonto Purworejo Jawa Tengah, Pusat Penelitian Geoteknologi LIPI, Bandung.

Mardiatno, Djati dan Sunarto, 2000, Tinjauan Geomorfologi Terapan Mengenai Bahaya Deflasi Di Kawasan Pesisir Parangtritis, Prosiding Seminar Nasional: Pengelolaan Ekosistem Pantai dan Pulau-Pulau Kecil Dalam Konteks Negara Kepulauan, ISBN: 979-8786-13-0, 102-106.

Pratistho, Bambang dan Nurcholis, M., 2000, Mewaspadai Dinamika Pesisir Daerah Istimewa Yogyakarta, Prosiding Seminar Nasional: Pengelolaan Ekosistem Pantai dan Pulau-Pulau Kecil Dalam Konteks Negara Kepulauan, ISBN: 979-8786-13-0, 107-114.

Reksohadiprodjo, S. dan Pradono, 1994, Ekonomi Sumber Daya Alam dan Energi: Edisi 2, BPFE Yogyakarta.

Reksohadiprodjo, S. dan Purnomo, B., 1992, Ekonomi Lingkungan, BPFE Yogyakarta.

Sungkowo, Andi. 2007. Ekosistem Gumuk Pasir di Bagian Selatan Kabupaten Kebumen Berperan Sebagai Penghambat Hempasan Tsunami, Prosiding Seminar Nasional: Eksistensi Kebumian, Pemanasan Global dan Pengelolaan Sumber Daya Alam, UPN "Veteran” Yogyakarta.

Verstappen, H. Th., 1983, Applied Geomorphology - Geomorphological Surveys For Environmental Development, ITC, Elsevier Science Publishing Company Inc, The Natherlands. 
